\title{
In vitro and in vivo activity and cross resistance profiles of novel ruthenium (II) organometallic arene complexes in human ovarian
}

\section{cancer}

\author{
RE Aird', J Cummings*,', AA Ritchie', M Muir', RE Morris², H Chen², PJ Sadler² and DI Jodrell' \\ 'Cancer Research UK, Edinburgh Oncology Unit, Western General Hospital, Crewe Road South, Edinburgh EH4 2XR, UK; ${ }^{2}$ Department of Chemistry, \\ University of Edinburgh, Edinburgh EH9 3JJ, UK
}

Ruthenium complexes offer the potential of reduced toxicity, a novel mechanism of action, non-cross resistance and a different spectrum of activity compared to platinum containing compounds. Thirteen novel ruthenium(II) organometallic arene complexes have been evaluated for activity (in vitro and in vivo) in models of human ovarian cancer, and cross-resistance profiles established in cisplatin and multi-drug-resistant variants. A broad range of $I C_{50}$ values was obtained $(0.5$ to $>100 \mu \mathrm{M})$ in A2780 parental cells with two compounds (RMI75 and HC29) equipotent to carboplatin (6 $\mu \mathrm{M}$ ), and the most active compound $(\mathrm{HCl})$ equipotent to cisplatin $(0.6 \mu \mathrm{M})$. Stable bi-dentate chelating ligands (ethylenediamine), a more hydrophobic arene ligand (tetrahydroanthracene) and a single ligand exchange centre (chloride) were associated with increased activity. None of the six active ruthenium(II) compounds were cross-resistant in the A2780cis cell line, demonstrated to be I0-fold resistant to cisplatin/carboplatin by a mechanism involving, at least in part, silencing of MLHI protein expression via methylation. Varying degrees of cross-resistance were observed in the P-I 70 glycoprotein overexpressing multi-drug-resistant cell line $2780^{A D}$ that could be reversed by co-treatment with verapamil. In vivo activity was established with RMI75 in the A2780 xenograft together with non-cross-resistance in the A2780cis xenograft and a lack of activity in the $2780^{\mathrm{AD}}$ xenograft. High activity coupled to non cross-resistance in cisplatin resistant models merit further development of this novel group of anticancer compounds.

British Journal of Cancer (2002) 86, 1652 - 1657. DOI: 10.1038/sj/bjc/6600290 www.bjcancer.com (c) 2002 Cancer Research UK

Keywords: ruthenium(II); organometallic arene complexes; structure activity relationships; drug resistance; ovarian xenografts

Metal complexes remain an important resource for the generation of chemical diversity in the search for novel therapeutic and diagnostic agents, especially in the arena of anticancer drug development (Guo and Sadler, 1999). Cis-dichlorodiammine platinum(II) (cisplatin) represents one of the most active and clinically useful agents used in the treatment of cancer, achieving cures in testicular cancer and high response rates in ovarian and small cell lung cancer (Giaccone, 2000). Evidence from both pre-clinical studies and clinical investigations has strongly implicated DNA as the biologic target for cisplatin through the formation of irreversible adducts via the process of ligand exchange (Jamieson and Lippard, 1999; Kelland, 2000). However, in common with many other cytotoxic drugs, cisplatin induces normal tissue toxicity, particularly to the kidney, and the development of acquired drug resistance can occur in initially responsive disease types (ovarian and small cell lung) or be present as intrinsic drug resistance in less-responsive disease types (non-small cell lung and colon) (Giaccone, 2000).

Based predominately on evidence from cell lines, the mechanistic basis for cisplatin resistance appears to be multi-factorial, involving drug transport defects (both reduced uptake and active

*Correspondence: Dr J Cummings; E-mail: jeffrey.cummings@cancer.org.uk Received 7 December 200 I; revised 7 February 2002; accepted 4 March 2002 efflux), detoxification by interaction with cellular nucleophiles, modulations in DNA repair pathways, and altered cellular signalling responses downstream of DNA damage (Fink et al, 1998; Johnson et al, 1998; Wang et al, 2000). A variety of approaches have been adopted to overcome both de novo and acquired cisplatin resistance, ranging from broad-based programmes of new platinum analogue design to specific attempts to modulate a single pathway of resistance (Judson and Kelland, 2000; Mimnaugh et al, 2000; Plumb et al, 2000).

The metal ruthenium $(\mathrm{Ru})$ possesses several favourable chemical properties that indicate it may be a strong candidate to form a basis for rational anticancer drug design (Clarke et al, 1999; Allardyce and Dyson, 2001). Ru complexes demonstrate similar ligand exchange kinetics to those of platinum (Pt II) while displaying only low toxicity, which in part is believed to be due to the ability to mimic iron in binding to plasma proteins including transferrin and albumin (Allardyce and Dyson, 2001). Transport and sequestration of $\mathrm{Ru}$ into tumour cells may be mediated via protein transport and receptor mediated uptake (Guo and Sadler, 1999). Due to differing ligand geometry between their complexes, $\mathrm{Ru}$ compounds bind to DNA forming predominately inter-strand crosslinks as opposed to the intra-strand crosslinks favoured by cisplatin (Fruhauf and Zeller, 1991; Gallori et al, 2000). In addition, non-nuclear targets, such as the mitochondrion and the cell surface, have also been implicated in the antineoplastic activity of $\mathrm{Ru}$ complexes, particularly in the case of the clinically investigated 
$\mathrm{Ru}(\mathrm{III})$ antimetastatic drug (trans $\left.-\mathrm{RuCl}_{4}(\mathrm{DMSO}) \mathrm{Im}\right)(\mathrm{ImH})$ (NAMI-A) (Bergamo et al, 2000). Thus, Ru complexes offer the potential over Pt (II) complexes of reduced toxicity, a novel mechanism of action, the prospect of non-cross resistance (Zeller et al, 1991; Coluccia et al, 1993) and a different spectrum of activity. Previous investigators have focused on $\mathrm{Ru}(\mathrm{III})$ complexes as potential antitumour agents (Keppler et al, 1987; Berger et al, 1989; Seelig et al, 1992). In the present study, a series of novel $\mathrm{Ru}(\mathrm{II})$ organometallic arene complexes (Morris et al, 2001) have been evaluated for activity in both in vitro and in vivo models of human ovarian cancer, and cross-resistance profiles established in cisplatin and multi-drug resistant (MDR) variants.

\section{MATERIALS AND METHODS}

\section{Investigational agents}

The 13 novel $\mathrm{Ru}$ (II) organometallic arene compounds (for formulae see Figure 1) were synthesised and chemically characterised as described in detail (Morris et al, 2001) and are quoted in the following patents: PCT/GB00/04144 and PCT/GB01/02824. All compounds were salts with $\mathrm{PF}_{6}{ }^{-}$as counter anion. Cisplatin, carboplatin and doxorubicin were obtained from the Western General Hospital pharmacy.

\section{Cell lines}

The A2780 human ovarian cancer cell line and its MDR counterpart $2780^{\mathrm{AD}}$ were kindly provided by Drs TC Hamilton and RF Ozols, Fox Chase Cancer Center, Philadelphia, USA. $2780^{\mathrm{AD}}$ was cultured in the presence of $2 \mu \mathrm{M}$ doxorubicin, which was removed

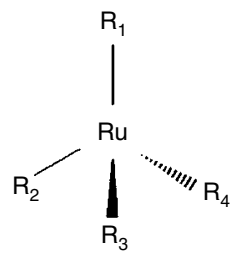

\begin{tabular}{|c|c|c|c|c|}
\hline COMPOUND & R1 & $\underline{\mathrm{R} 2}$ & $\underline{\mathrm{R} 3}$ & $\underline{\text { R4 }}$ \\
\hline RM100 & p-cymene & $\mathrm{Cl}$ & $\mathrm{CH}_{3} \mathrm{CN}$ & $\mathrm{CH}_{3} \mathrm{CN}$ \\
\hline RM101 & p-cymene & $\mathrm{Br}$ & $\mathrm{CH}_{3} \mathrm{CN}$ & $\mathrm{CH}_{3} \mathrm{CN}$ \\
\hline RM114 & p-cymene & $\mathrm{Cl}$ & $\mathrm{Cl}$ & isonicotinamide \\
\hline RM116 & p-cymene & $\mathrm{Cl}$ & \multicolumn{2}{|c|}{$\mathrm{H}_{2} \mathrm{NCH}_{2} \mathrm{CH}_{2} \mathrm{NH}_{2}$} \\
\hline RM118 & $\mathrm{C}_{6} \mathrm{H}_{6}$ & 1 & \multicolumn{2}{|c|}{$\mathrm{H}_{2} \mathrm{NCH}_{2} \mathrm{CH}_{2} \mathrm{NH}_{2}$} \\
\hline RM119 & $\mathrm{C}_{6} \mathrm{H}_{6}$ & $\mathrm{Cl}$ & \multicolumn{2}{|c|}{$\mathrm{H}_{2} \mathrm{NCH}_{2} \mathrm{CH}_{2} \mathrm{NH}_{2}$} \\
\hline RM121 & p-cymene & 1 & \multicolumn{2}{|c|}{$\mathrm{H}_{2} \mathrm{NCH}_{2} \mathrm{CH}_{2} \mathrm{NH}_{2}$} \\
\hline RM125 & $\mathrm{C}_{6} \mathrm{H}_{5} \mathrm{CO}_{2} \mathrm{CH}_{3}$ & $\mathrm{Cl}$ & \multicolumn{2}{|c|}{$\mathrm{H}_{2} \mathrm{NCH}_{2} \mathrm{CH}_{2} \mathrm{NH}_{2}$} \\
\hline RM168 & $\mathrm{C}_{6} \mathrm{H}_{5} \mathrm{CO}_{2} \mathrm{CH}_{2} \mathrm{CH}_{3}$ & $\mathrm{Cl}$ & \multicolumn{2}{|c|}{$\mathrm{H}_{2} \mathrm{NCH}_{2} \mathrm{CH}_{2} \mathrm{NH}_{2}$} \\
\hline RM175 & $\mathrm{C}_{6} \mathrm{H}_{5} \mathrm{C}_{6} \mathrm{H}_{5}$ & $\mathrm{Cl}$ & \multicolumn{2}{|c|}{$\mathrm{H}_{2} \mathrm{NCH}_{2} \mathrm{CH}_{2} \mathrm{NH}_{2}$} \\
\hline HC11 & Tetrahydroanthracene & $\mathrm{Cl}$ & \multicolumn{2}{|c|}{$\mathrm{H}_{2} \mathrm{NCH}_{2} \mathrm{CH}_{2} \mathrm{NH}_{2}$} \\
\hline HC27 & Dihydroanthracene & $\mathrm{Cl}$ & \multicolumn{2}{|c|}{$\mathrm{H}_{2} \mathrm{~N}\left(\mathrm{CH}_{2}\right)_{2} \mathrm{NH}\left(\mathrm{CH}_{2} \mathrm{CH}_{3}\right)$} \\
\hline $\mathrm{HC} 29$ & $\mathrm{C}_{6} \mathrm{H}_{5} \mathrm{C}_{6} \mathrm{H}_{5}$ & $\mathrm{Cl}$ & \multicolumn{2}{|c|}{$\mathrm{H}_{2} \mathrm{~N}\left(\mathrm{CH}_{2}\right)_{2} \mathrm{NH}\left(\mathrm{CH}_{2} \mathrm{CH}_{3}\right)$} \\
\hline
\end{tabular}

Figure I Molecular formulae of novel Ruthenium (II) organometallic complexes.
1 week prior to experimentation with the $\mathrm{Ru}(\mathrm{II})$ compounds. The A2780cis cell line was obtained from the ECACC (European collection of cell culture, Salisbury, UK). Cells were grown as monolayers in RPMI 1640 medium with L-glutamine (Gibco BRL, Paisley, UK) supplemented with $5 \%$ foetal calf serum and penicillin $\left(110 \mathrm{U} \mathrm{ml}^{-1}\right)$ and streptomycin $\left(100 \mu \mathrm{g} \mathrm{ml}^{-1}\right)$ and were maintained under standard tissue culture conditions of $37^{\circ} \mathrm{C}$ and $5 \%$ $\mathrm{CO}_{2}$. Experiments were performed on cells within 10 passages of each other.

\section{In vitro growth inhibition assays}

The human ovarian cells were added at a density of $1 \times 10^{4}$ cells per well to 24-well tissue culture trays (Falcon Plastics, Becton Dickinson, Lincoln Park, NJ, USA) and allowed to grow for $72 \mathrm{~h}$ before addition of the $\mathrm{Ru}(\mathrm{II})$ arene complexes. Stock solutions of the ruthenium compounds were made up fresh in deionised water and sonicated to ensure complete dissolution. These stock solutions were diluted with media to give final concentrations ranging between 0.1 and $100 \mu \mathrm{M}$. All the compounds were evaluated at each concentration in duplicate wells, and complete assays were repeated a minimum of three times. Cisplatin or carboplatin was employed as a positive and comparative control in each experiment. After 24-h exposure the drug-containing medium was removed, the cells washed with phosphate buffered saline (PBS) and fresh medium was added. Cell number was assessed after a further $72 \mathrm{~h}$ growth using a Coulter counter (Coulter Electronics Ltd, Luton, UK) and the $\mathrm{IC}_{50}$ values (concentration of drug causing $50 \%$ growth inhibition) calculated by linear regression analysis comparing the inhibitory effects of the drugs against the growth of untreated cells.

\section{Co-incubation of human ovarian cell lines with verapamil or $2^{\prime}$ deoxy-5-azacytidine (DAC)}

Cells were cultured in 24-well plates as above. Verapamil (50 $\mu \mathrm{M}$, Sigma Chemical Co., Poole, UK) was added concomitantly with the $\mathrm{Ru}(\mathrm{II})$ test compounds or $\mathrm{Pt}(\mathrm{II})$ compounds and doxorubicin control for $24 \mathrm{~h}$ and growth inhibition was then established as above. DAC ( $0.5 \mu \mathrm{M}$, Sigma) was added to cells for 3 days prior to being removed with PBS washes and then the cells were treated with cisplatin for $24 \mathrm{~h}$ and growth inhibition was then established as above.

\section{Immunoblotting for MLH1}

A2780, A2780cis and $2780^{\mathrm{AD}}$ cells were plated down at a density of $5 \times 10^{5}$ cells per well in 6-well trays and harvested when $70 \%$ confluent. Extracts were prepared by suspending the cell pellets in $50 \mathrm{~mm}$ HEPES (pH7.4), 1\% Triton X-100, $150 \mathrm{mM} \mathrm{NaCl}$, $5 \mathrm{mM}$ EDTA and $0.5 \%$ sodium deoxycholate in the presence of a standard cocktail of protease inhibitors (Sigma). Protein concentrations were determined by the Bio-Rad protein assay (Bio-Rad, Richmond, CA, USA). Samples $(20 \mu \mathrm{g})$ were denatured and separated on a $10 \%$ SDS polyacrylamide gel before being transferred to nitrocellulose and probed using a mouse monoclonal antibody for hMLH1 (Clone G168-15, Pharmingen). Blots were visualised by ECL detection (Santa Cruz). Levels of protein loading were examined using an actin antibody (Calbiochem). In a separate study, A2780 and A2780cis cells were treated with $10 \mu \mathrm{M}$ DAC for 3 days prior to protein extraction and SDS polyacrylamide gel electrophoresis as above.

\section{Antitumour activity in human ovarian cancer xenografts}

The antitumour activity of the novel $\mathrm{Ru}(\mathrm{II})$ organometallic arene complexes was evaluated in A2780, 2780 $\mathrm{AD}$ and A2780cis xenografts growing in $n u / n u$ mice essentially as described previously 
(Cummings et al, 1996). The three xenografts were established from their respective cell lines by subcutaneous implantation of $5 \times 10^{6}$ cells in serum free media in the flank of animals. The resultant xenografts were subjected to regular pathologic examination to confirm the human ovarian cancer phenotype. All animal experiments were carried out with local and The Imperial Cancer Research Fund ethical committee approval. The ethical guidelines that were followed meet the standards required by the UKCCCR guidelines (Workman et al, 1998). Female nu/nu mice were implanted with $2-3 \mathrm{~mm}^{3}$ fragments of viable tumour and left for approximately 3-4 weeks. Animals were randomised into control and drug treated groups, each of which contained 5-10 mice. $\mathrm{Ru}$ (II) complexes were administered as $10 \%$ DMSO solutions in sterile saline and cisplatin as a solution in sterile saline both at a volume of $0.1 \mathrm{ml} / 10 \mathrm{~g}$ of body weight i.p. Tumour volumes were determined by calliper measurement and calculated using the formula: volume $=0.5 \times$ length $\times$ width $^{2}$. Relative tumour volume (RTV) was then calculated for each individual tumour by dividing tumour volume on day $\mathrm{t}$ by the tumour volume on day $1 \times 100 \%$. T/C (\%) values were calculated as the mean tumour volume of the drug treated group/mean tumour volume of the control group $\times 100$ from the data generated as indicated below. Antitumour activity studies were performed on either two or three separate occasions.

\section{RESULTS}

Structure activity relationship for $\mathrm{Ru}(\mathrm{II})$ organometallic arene complexes in A2780 human ovarian cancer cells

The 13 organometallic complexes were initially screened against the platinum sensitive human ovarian cancer cell line A2780 in order to establish a baseline level of growth inhibitory activity (Brown et al, 1993). A broad range of $\mathrm{IC}_{50}$ values was obtained (see Table 1) with two compounds (RM175 and HC29) equipotent to carboplatin $(6 \mu \mathrm{M})$, one compound (HC11) equipotent to cisplatin $(0.6 \mu \mathrm{M})$ and one compound (HC27) intermediate in potency between the two platinum complexes. Three compounds (RM 100, 101 and 114) recorded values greater than $100 \mu \mathrm{M}$ and were defined essentially as inactive, and the remaining six compounds were of intermediate value $\left(\mathrm{IC}_{50}, 9-56 \mu \mathrm{M}\right)$. Of interest, RM100, RM101 and RM114 when originally tested shortly after synthesis yielded $\mathrm{IC}_{50}$ values of 7,8 and $11 \mu \mathrm{M}$ respectively, but these decayed over a period of 12 weeks to $>100 \mu \mathrm{M}$ even while stored in the solid state at $4^{\circ} \mathrm{C}$. These compounds alone contained more reactive monodentate ligands such as acetonitrile at positions R3 and R4 (see Figure 1) in comparison to the more stable chelat-

Table I IC 50 values of Ru(II) complexes in A2780 cells after a $24 \mathrm{~h}$ drug exposure

\begin{tabular}{lc}
\hline Ru(II) complex & IC $_{\mathbf{5 0}}(\mu \mathbf{M})^{*}$ \\
\hline RMI00 & $>100$ \\
RMI0I & $>100$ \\
RMII4 & $>100$ \\
RMII6 & $10 \pm 1.1$ \\
RMII8 & $20 \pm 8.9$ \\
RMII9 & $17 \pm 8.3$ \\
RMI2I & $9 \pm 1.6$ \\
RMI25 & $56 \pm 0.7$ \\
RMI68 & $52 \pm 2.3$ \\
RMI75 & $5 \pm 0.4$ \\
HCII & $0.5 \pm 0.1$ \\
HC27 & $2 \pm 0.4$ \\
HC29 & $6 \pm 0.7$ \\
Cisplatin & $0.6 \pm 0.06$ \\
Carboplatin & $6.0 \pm 0.7$ \\
\hline
\end{tabular}

*Results expressed as mean \pm s.e. of $\geqslant$ three separate experiments. ing ligand ethylenediamine (en) or N-ethyl ethylenediamine employed in the remaining compounds. Substitution of the proposed halide reactive centre (R2, Figure 1) with iodide as opposed to chloride had little effect on in vitro potency (compare RM118 with RM119 and RM116 with RM121). Minor chemical alterations to the en chelating ligand (HC29 vs RM175, Figure 1 and Table 2) also had little effect on potency. However, substitution at position R1 (the arene ligand) from benzene (RM119) to p-cymene (RM116) to biphenyl (RM175) to dihydroanthracene (HC27) to tetrahydroanthracene (HC11) increasing overall hydrophobicity resulted in a large increase in growth inhibitory activity from $\left(\mathrm{IC}_{50}\right) 17$ to 10 to 5 to 2 to $0.5 \mu \mathrm{m}$. The arene ligand is believed to play a role in preventing oxidation of the ruthenium from oxidation state II (the proposed biologically active form) to oxidation state III (proposed inactive, prodrug form) (Allardyce and Dyson, 2001; Morris et al, 2001). It may also facilitate cellular uptake of the compounds.

\section{Cross resistance profiles of $\mathrm{Ru}(\mathrm{II})$ organometallic arene complexes}

The fold resistance values for the six most active compounds RM116, 121, 175 and HC11, 27 and 29 in the $2780^{\mathrm{AD}}$ MDR and A2780cis cisplatin resistant variants are listed in Table 2. Compared to the parental cell line (A2780), a relatively high degree of crossresistance was observed in $2780^{\mathrm{AD}}$ ranging from a factor of 15 for RM116 up to $>100$ for HC11 and this is compared to 87-fold for doxorubicin, the original selection agent (Louie et al, 1986) (see Table 2). In addition, there was an eight-fold level of resistance to cisplatin in $2780^{\mathrm{AD}}$. By contrast, in A2780cis cells the six organometallic complexes together with doxorubicin were completely non-cross resistant, while cisplatin and carboplatin were both 10 fold cross resistant (Table 2).

\section{Mechanisms of drug resistance}

Verapamil has been shown to effectively abrogate P-gp mediated active efflux of anticancer drugs in ovarian cancer cells by competitive inhibition of drug transport and reverse multi-drug resistance (Rogan et al, 1984). The influence of verapamil on the level of cross-resistance in $2780^{\mathrm{AD}}$ to RM175, cisplatin and doxorubicin was evaluated. With doxorubicin, $50 \mu \mathrm{M}$ verapamil restored the chemosensitivity of the MDR cell line back to that of the parental cell line (Figure 2). In a previous study we have demonstrated that verapamil was able to completely abolish doxorubicin active efflux in $2780^{\mathrm{AD}}$ (Cummings et al, 1996). As anticipated, verapamil had little effect on the activity of cisplatin, consistent with its known lack of recognition by P-gp (Allen et al, 2000). In the case of the $\mathrm{Ru}$ (II) compound RM175, verapamil was also highly effective at restoring sensitivity (Figure 2). Here, cross resistance fell from a factor of 38 to only three-fold.

Cisplatin resistance is frequently associated with loss of proficiency of the mismatch repair pathway due to methylation and silencing of the MLH1 gene (Brown et al, 1997; Plumb et al, 2000). The A2780cis cell line was confirmed to lack MLH1 protein as well as $2780^{\mathrm{AD}}$, while the parental cell line expressed the protein (Figure 3a). Treatment with the demethylating agent DAC had little effect on MLH1 protein levels in parental A2780 cells (Figure $3 \mathrm{~b})$. However, it recovered expression of the protein in the A2780cis cell lines almost back to that of the wild-type cells (Figure $3 \mathrm{~b})$. In addition, DAC was able to partially reverse drug resistance to cisplatin in A2780cis cells by a factor of two-fold.

\section{Antitumour activity of RM175}

In preliminary studies it was established that the maximum tolerated dose (MTD) of cisplatin was $10 \mathrm{mg} \mathrm{kg}^{-1}$ i.p. as a single administration, in keeping with previous reports (Langdon et al, 
Table 2 Cross resistance profiles of $\mathrm{Ru}(\mathrm{II})$ complexes in cisplatin resistant A2780cis cells and multi-drug resistant $2780^{\mathrm{AD}}$ cells compared to parental A2780 cells

\begin{tabular}{lcc}
\hline & \multicolumn{2}{c}{ Fold resistance } \\
\cline { 2 - 3 } Complex & A2780cis & $\mathbf{2 7 8 0}^{\mathbf{A D}}$ \\
\hline RMI16 & 0.6 & 15 \\
RMI2I & 0.4 & 27 \\
RMI75 & 1.0 & 38 \\
HCII & 1.0 & $>100$ \\
HC27 & 1.0 & $>100$ \\
HC29 & 0.7 & 40 \\
Cisplatin & 10 & 8.0 \\
Carboplatin & 10 & $\mathrm{ND}$ \\
Doxorubicin & 1.0 & 87 \\
\hline
\end{tabular}

$\mathrm{ND}=$ not determined

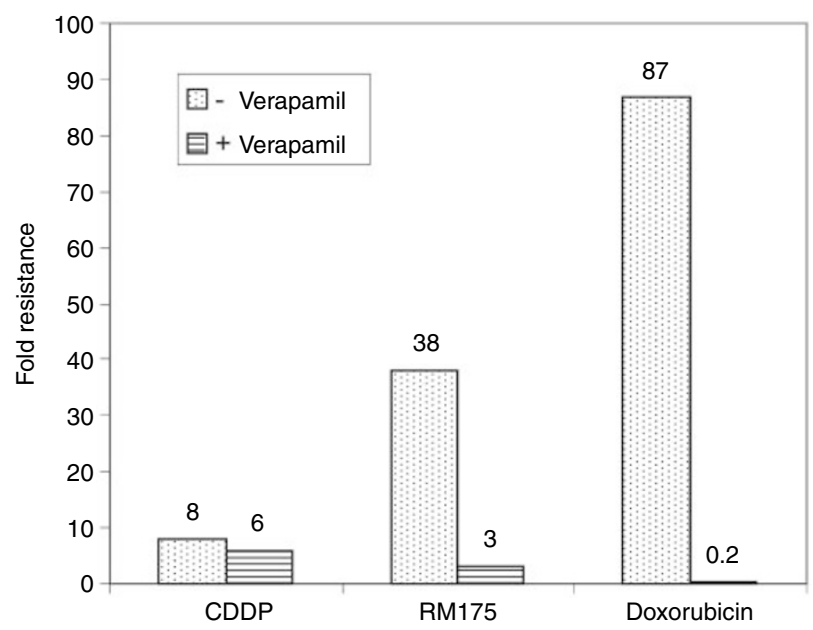

Figure 2 Effect of co-administration of $50 \mu \mathrm{M}$-verapamil on the degree of cross-resistance exhibited in the $2780^{\mathrm{AD}}$ multi-drug resistant cell line to doxorubicin, cisplatin and the novel Ru(II) arene complex RMI75 (for structure see Figure I)

1994). Mice were able to tolerate up to $25 \mathrm{mg} \mathrm{kg}^{-1} \mathrm{RM} 175$ on days 1 and 5 without significant weight loss. At the above dose regimen, RM175 produced a significant growth delay against the A2780 xenograft representing a T/C value of $46 \%$ on day 16 (Student's $t$-test compared to controls, Figure 4a). By comparison cisplatin at its MTD produced a T/C value of $23 \%$ on day 16 of the study (Figure 4a). In the A2780cis xenograft RM175 growth inhibitory activity was maintained ( $\mathrm{T} / \mathrm{C} 51 \%$, day 13 ) and was significantly greater than that of cisplatin on day $8(P=0.03)$ and day $13(P=0.01)$ (Figure $4 \mathrm{~b})$. Cisplatin was active in the $2780^{\mathrm{AD}}$ xenograft, although not to the same level as the parental xenograft ( $\mathrm{T} / \mathrm{C}$ value $55 \%$, day 14 ), while RM175 was inactive against $2780^{\mathrm{AD}}$ (Figure 4c). Thus, the patterns of activity established in vitro for both RM175 and cisplatin were mirrored to a large degree in vivo, making the A2780 cell line and its two resistant clones an attractive pre-clinical screen for evaluating new agents in this class (Workman et al, 1998).

\section{DISCUSSION}

The aim of the present study has been to evaluate the in vitro and in vivo the activity of a novel series of $\mathrm{Ru}(\mathrm{II})$ organometallic arene complexes and identify potential resistance mechanisms, with the intention of feeding back this information into rational design of second generation compounds. $\mathrm{Ru}(\mathrm{II})$ arene complexes with in
A

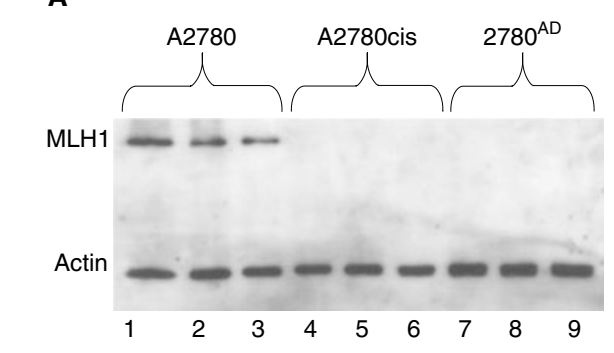

B
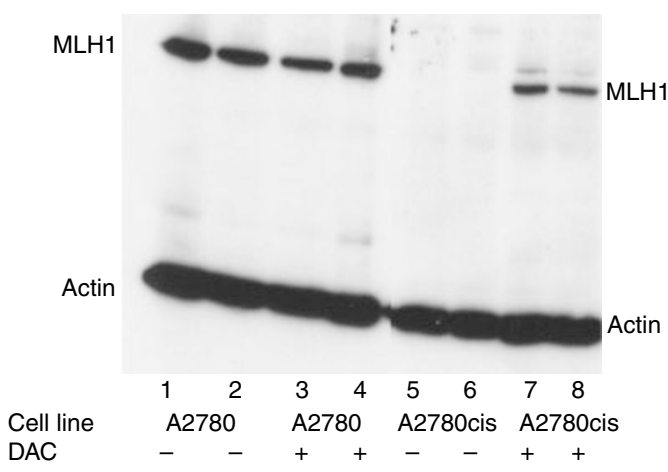

Figure 3 (A) MLHI protein levels in the A2780 (lanes I-3), 2780cis (lanes 4-6) and $2780^{A D}$ (lanes 7-9) determined by Western blot analysis. (B) MLHI protein levels in the A2780 and A2780cis cell lines plus $(+)$ or minus (-) co-incubation with $10 \mu \mathrm{M}$ 2'deoxy-5-azacytidine (DAC) for 3 days prior to protein extraction and SDS polyacrylamide gel electrophoresis and Western blotting.

vitro potency greater than that of carboplatin and equal to cisplatin were identified, and in vivo xenograft activity was established in human ovarian cancer. A pattern of cross-resistance emerged for the $\mathrm{Ru}(\mathrm{II})$ arene compounds, quite distinct from that of cisplatin and carboplatin, characterised by non-cross resistance in cisplatin resistant cells (and xenograft) but cross-resistance in multi-drug resistant (MDR) cells (and xenograft).

The $2780^{\mathrm{AD}}$ cell line utilised in the present study displays the classic MDR phenotype mediated via over-expression of the $170 \mathrm{kD}$ plasma membrane glycoprotein P-gp and reduced cellular drug accumulation (Cummings et al, 1995, 1996). In addition, multi-drug (associated) protein 2 (MRP2) is up-regulated in this cell line (Cummings et al, unpublished observations). Over-expression of MRP2 is a common phenomenon in human ovarian cell lines (including A2780) that display higher levels of resistance to cisplatin (Borst et al, 2000; Kool et al, 1997). However, MLH1 protein was also shown to be absent, which may be responsible for the eight-fold level of drug resistance observed with cisplatin in $2780^{\mathrm{AD}}$ (Table 2). P-pg displays striking substrate specificity for naturally occurring hydrophobic molecules, particularly those carrying a positive charge but does not transport cisplatin (Endicott and Ling, 1989; Gottesman and Pastan, 1993; Seelig et al, 2000). By contrast, MRPs 1, 2 are 3 are well recognised as transporting organic anions, or neutral compounds as either glutathione (GSH) conjugates or co-transported with GSH (Borst et al, 2000; Ishikawa et al, 2000; Zeng et al, 2000). The six organometallic complexes investigated for cross-resistance in the present study (see Table 2 and Figure 1) exhibit both of the features - hydrophobicity and a cationic centre - that facilitate substrate recognition by P-pg (Endicott and Ling, 1989; Gottesman and Pastan, 1993; Seelig et $a l, 2000)$. Thus, it is likely that the cross-resistance to $\mathrm{Ru}(\mathrm{II})$ arene complexes observed in the $2780^{\mathrm{AD}}$ cell line is due, at least in part, to recognition and active efflux by $\mathrm{P}$-pg. The almost complete 
A

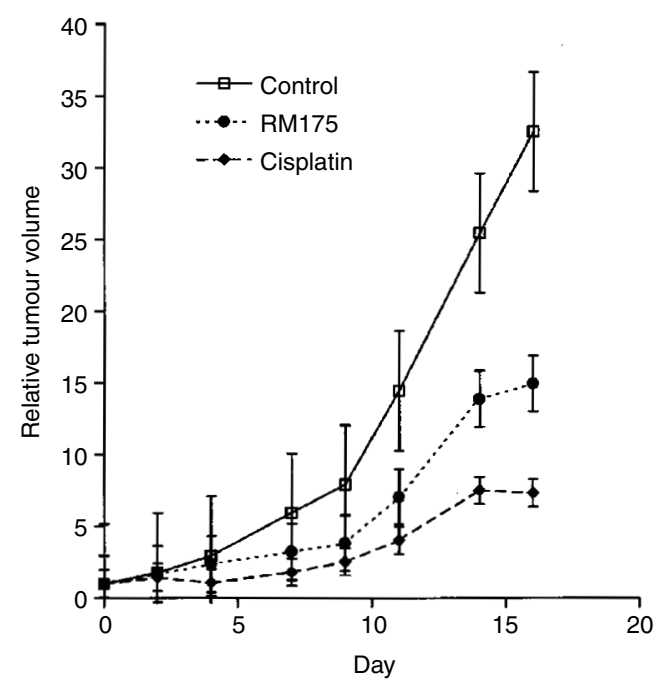

B

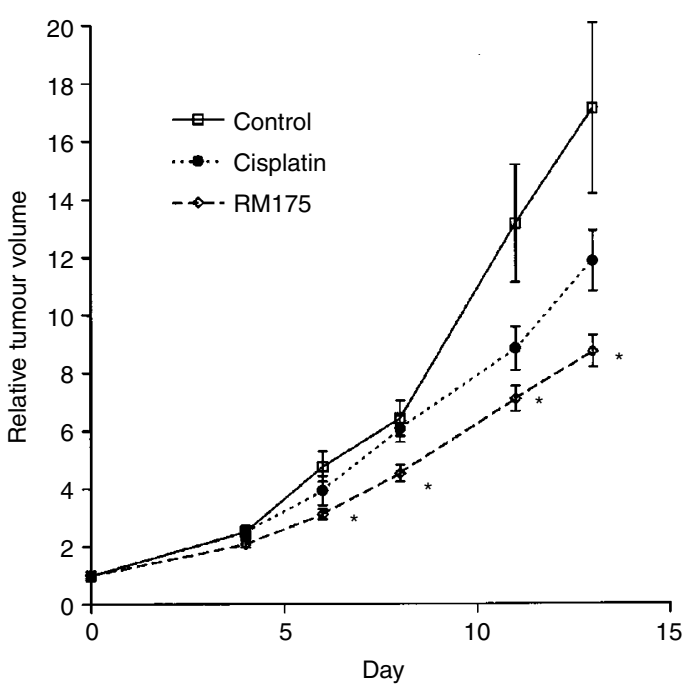

C

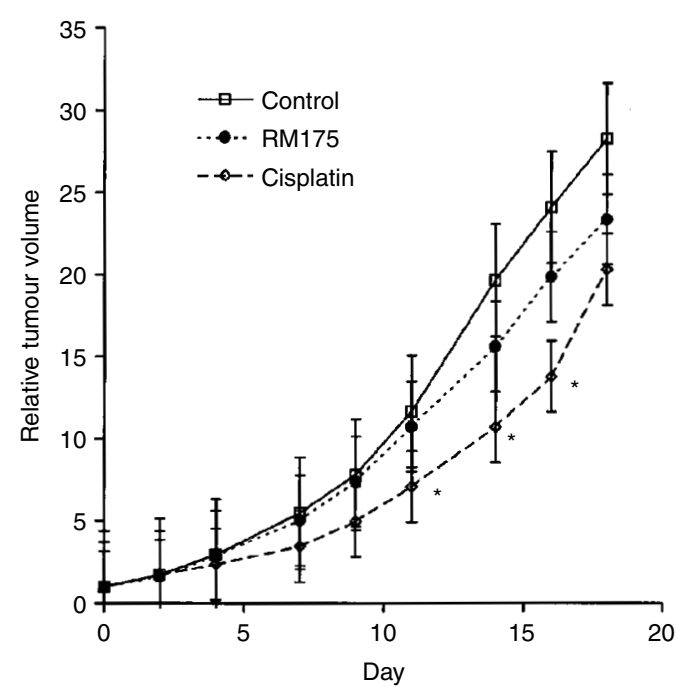

Figure 4 Antitumour activity of RMI75 administered on days I and 5 at $25 \mathrm{mg} \mathrm{kg}^{-1}$ i.p. vs cisplatin administered on day I at $10 \mathrm{mg} \mathrm{kg}^{-1}$ i.p. (A) Effect of RMI 75 and cisplatin on the A2780 human ovarian cancer xeno- reversal of RM175 drug resistance by verapamil suggests that P-gp may function as the pre-dominant or even sole drug-resistance mechanism in this cell line. It is noteworthy that the more hydrophobic the organometallic complex, the higher the level of intrinsic drug potency in A2780 parental cells, but also the greater the degree of cross-resistance in $2780^{\mathrm{AD}}$.

The mechanism of resistance to cisplatin in A2780cis cells remains poorly characterised (ECACC catalogue, European collection of cell culture, Salisbury, UK). A number of potential resistance mechanisms to cisplatin and analogous alkylating agents in a variety of A2780 clones have been reported previously including:

(a) loss of proficiency of the mismatch repair pathway (MMR) due to methylation and silencing of the $h M L H 1$ gene (Brown et al, 1997) (Plumb et al, 2000);

(b) accumulation of the mutant (inactive) form of the p53 tumour suppressor gene (Brown et al, 1993);

(c) elevated GSH cellular content and a concomitant increase in expression of MRP2 (Kool et al, 1997) and

(d) altered DNA damage recognition, cellular signalling and DNA repair (Roy et al, 2000).

Since the novel $\mathrm{Ru}(\mathrm{II})$ organometallic complexes were unaffected by these putative mechanisms, it was important to establish the mechanism(s) of cisplatin resistance in A2780cis. In the present study, Western blot analysis of the MLH1 protein in A2780 parental (cisplatin sensitive) cells and A2780cis (cisplatin resistant) cells clearly demonstrated that it was not present in the resistant cell line. Treatment of A2780cis cells with DAC re-established MLH1 protein expression and partially reversed drug resistance to cisplatin. DAC has recently been shown to reverse cisplatin drug resistance in the related A2780/cp70 xenograft by demethylation of the $h M L H 1$ gene promoter (Plumb et al, 2000). Thus, it would appear that a deficiency in MMR is at least partially responsible for the expression of cisplatin resistance in the A2780cis cell line and by implication that MMR proficiency is not a prerequisite in the mechanism of action of the novel $\mathrm{Ru}$ (II) compounds, consistent with a number of other ruthenium complexes (Fruhauf and Zeller, 1991; Zeller et al, 1991; Coluccia et al, 1993; Kelland, 1999). MMR deficiency usually accounts for a 2-3-fold level of resistance (Fink et al, 1998) and in the present study co-administration of DAC was only able to reverse cisplatin resistance in A2780cis by two-fold indicating the possibility of the presence of other resistance mechanisms in this cell line. At present, studies are in progress in the A2780cis cell line to investigate the role of drug transport, expression of drug transporters, levels of GSH and the role of p53.

In summary, a series of novel $\mathrm{Ru}(\mathrm{II})$ organometallic arene complexes have been evaluated for activity both in vitro and in vivo in human ovarian cancer. Preliminary structure activity data have been obtained suggesting that stable (chelating) bystander ligands, a more hydrophobic arene ligand (possibly to enhance cellular penetration) and a single ligand exchange centre are associated with reproducible and increased growth inhibitory activity. These properties, particularly the hydrophobic arene group may also promote recognition by $\mathrm{P}$-gp. Reduced in vivo toxicity and non cross-resistance in cisplatin resistant models in vitro and in vivo have been confirmed, justifying further development of this novel and interesting group of metal complexes.

graft. (B) Effect of RMI75 and cisplatin on the A2780cis human ovarian cancer xenograft and $(\mathbf{C})$ effect of RMI 75 and cisplatin on the $2780^{\mathrm{AD}}$ human ovarian cancer xenograft. Statistical significance was evaluated by Student's $t$-test comparing the drug treated groups at specific time points against the control group: $* P<0.05$. In the case of $A 2780$, cisplatin was more active than RMI75 on days 14 and $16(P<0.01)$, while in A2780cis RMI75 was more active than cisplatin on days 8 and 13 $(P<0.05)$. 


\section{REFERENCES}

Allardyce CS, Dyson PJ (2001) Ruthenium in medicine: current clinical uses and future prospects. Platinum Metals Rev 45: 62-69

Allen JD, Brinkhuis RF, vanDeemter L, Wijnholds J, Schinkel AH (2000) Extensive contribution of the multidrug transporters P-glycoprotein and Mrp1 to basal drug resistance. Cancer Res 60: 5761-5766

Bergamo A, Zorzet S, Gava B, Sorc A, Alessio E, Iengo E, Sava G (2000) Effects of NAMI-A and some related ruthenium complexes on cell viability after short exposure of tumour cells. Anticancer Drugs 11: 665-672

Berger MR, Garzon FT, Keppler BK, Schmahl D (1989) Efficacy of new ruthenium complexes against chemically induced autochthonous colorectal carcinoma in rats. Anticancer Res 9: $761-765$

Borst P, Evers R, Kool M, Wijnholds J (2000) A family of drug transporters: the multidrug resistance-associated proteins. J Natl Cancer Inst 92: 1295 1302

Brown R, Clugston C, Burns P, Edlin A, Vasey P, Vojtesek B, Kaye S (1993) Increased accumulation of $\mathrm{p} 53$ protein in cisplatin-resistant ovarian cancer cell lines. Int J Cancer 55: 678-684

Brown R, Hirst GL, Gallagher WM, McIlwrath AJ, Margison GP, van der Zee A, Anthoney DA (1997) hMLH1 expression and cellular responses of ovarian tumour cells to treatment with cytotoxic anticancer agents. Oncogene 15: $45-52$

Clarke MJ, Zhu F, Frasca DR (1999) Non-platinum chemotherapeutic metallopharmaceuticals. Chem Rev 99: 2511-2533

Coluccia M, Sava G, Loseto F, Nassi A, Boccarelli A, Giordano D, Alessio E, Mestroni G (1993) Anti-leukaemic action of RuCl2 (DMSO) 4 isomers and prevention of brain involvement on P388 leukaemia and on P388/DDP subline. Eur J Cancer 29A:: 1873-1879

Cummings J, Macpherson JS, Meikle I, Smyth JF (1996) Development of anthracenyl-amino acid conjugates as topoisomerase I and II inhibitors that circumvent drug resistance. Biochem Pharmacol 52: 979-990

Cummings J, Meikle I, Macpherson JS, Smyth J (1995) Accumulation of anthracenyl-amino acid topoisomerase I and II inhibitors in drug sensitive and drug resistant human ovarian cancer cell lines determined by HPLC. Cancer Chemother Pharmacol 37: $103-109$

Endicott JA, Ling V (1989) The Biochemistry of P-glycoprotein-mediated multidrug resistance. Ann Rev Biochem 58: $137-171$

Fink D, Aebi S, Howell SB (1998) The role of DNA mismatch repair in drug resistance. Clinical Cancer Res 4: 378-387

Fruhauf S, Zeller WJ (1991) New platinum, titanium, and ruthenium complexes with different patterns of DNA damage in rat ovarian tumour cells. Cancer Res 51: $2943-2948$

Gallori E, Vettori C, Alessio E, Vilchez FG, Vilaplana R, Orioli P, Casini A, Messori L (2000) DNA as a possible target for antitumour ruthenium(III) complexes. Arch Biochem Biophys 376: 156-162

Giaccone G (2000) Clinical perspective on platinum resistance. Drugs 59: 9 17

Gottesman M, Pastan I (1993) Biochemistry of multidrug resistance mediated by the multidrug transporter. Ann Rev Biochem 62: 385-427

Guo Z, Sadler PJ (1999) Metals in Medicine. Angew Chem Int Ed 38: $1512-$ 1531

Ishikawa T, Kuo MT, Furuta K, Suzuki M (2000) The human multidrug resistance-associated protein (MRP) gene family: From biological function to drug molecular design. Clin Chem Lab Med 38: 893-897

Jamieson ER, Lippard S-J (1999) Structure, recognition and processing of cisplatin-DNA adducts. Chem Rev 99: 2467-2498

Johnson SW, Ferry KV, Hamilton TC (1998) Recent insights into platinum drug resistance in cancer. Drug Res Updates 1: 243-254
Judson I, Kelland LR (2000) New developments and approaches in the platinum arena. Drugs 59: 29-36

Kelland LR (1999) Meeting report on 8th International Symposium on Platinum and Other Metal Coordination Compounds in Cancer Chemotherapy. J Inorg Biochem 77: 121-124

Kelland LR (2000) Preclinical perspective on platinum resistance. Drugs 59: $1-8$

Keppler BK, Balzer W, Seifried V (1987) Synthesis and antitumour activity of triazolium-bis(triazole)-tetrachlororuthenate (III) and bistriazolium-triazolepentachlororuthenate (III). Two representatives of a new class of inorganic antitumour agents. Arzneimittelforschung 37: 770-771

Kool M, de Hass M, Scheffer GL, Scheper RJ, van Eijk MJT, Juijn JA, Baas F, Borst P (1997) Analysis of expression of cMOAT (MRP2), MRP3, MRP4 and MRP5, homologues of the multidrug resistance-associated protein gene (MRP1), in human cancer cells. Cancer Res 57: 3537 - 3547

Langdon SP, Hendriks HR, Braakhuis B-J, Pratesi G, Berger DP, Fodstad O, Fiebig HH, Boven E (1994) Preclinical phase II studies in human tumour xenografts. Anal Oncol 5: 415-422

Louie K, Hamilton T, Winker M, Berhens B, Tsuruo T, Klecker Jr R, McKoy W, Grotzinger K, Myers C, Young R, Ozols R (1986) Adriamycin accumulation and metabolism in adriamycin-sensitive and -resistant human ovarian cancer cell lines. Biochem Pharmacol 35: 467-472

Mimnaugh EG, Yunmbam MK, Li QD, Bonvini P, Hwang SG, Trepel J, Reed E, Neckers L (2000) Prevention of cisplatin-DNA adduct repair and potentiation of cisplatin-induced apoptosis in ovarian carcinoma cells by proteasome inhibitors. Biochem Pharmacol 60: 1343-1354

Morris RE, Aird RE, Murdoch PdS, Chen H, Cummings J, Hughes ND, Parson S, Parkin A, Boyd G, Jodrell DI, Sadler PJ (2001) Inhibtion of cancer cell growth by ruthenium arene complexes. J Med Chem 44: $3616-3621$

Plumb JA, Strathdee G, Sludden J, Kaye SB, Brown R (2000) Reversal of drug resistance in human tumor xenografts by $2^{\prime}$-deoxy-5-azacytidine-induced demethylation of the hMLH1 gene promoter. Cancer Res 60: 6039-6044

Rogan AM, Hamilton TC, Young RC, Klecker JRW, Ozols RF (1984) Reversal of adriamycin resistance by verapamil in human ovarian cancer. Science 224: $994-996$

Roy G, Horton JK, Roy R, Denning T, Mitra S, Boldogh I (2000) Acquired alkylating drug resistance of a human ovarian carcinoma cell line is unaffected by altered levels of pro- and anti-apoptotic proteins. Oncogene 19: $141-150$

Seelig A, Blatter XL, Wohnsland F (2000) Substrate recognition by P-glycoprotein and the multidrug resistance-associated protein MRP1: a comparison. Int J Clin Pharmacol Ther 38: 111-121

Seelig MH, Berger MR, Keppler BK (1992) Antineoplastic activity of three ruthenium derivatives against chemically induced colorectal carcinoma in rats. J Cancer Res Clin Oncol 118: $195-200$

Wang XT, Martindale JL, Holbrook NJ (2000) Requirement for ERK activation in cisplatin-induced apoptosis. J Biol Chem 275: $39435-39443$

Workman P, Twentyman P, Balkwill F, Balmain A, Chaplin D, Double J, Embleton J, Newell D, Raymond R, Stables J, Stephens T, Wallace J (1998) United Kingdom Co-ordinating Committee on Cancer Research (UKCCCR) guidelines for the welfare of animals in experimental neoplasia. Br J Cancer 77: 1-10

Zeller WJ, Fruhauf S, Chen G, Keppler BK, Frei E, Kaufmann M (1991) Chemoresistance in rat ovarian tumours. Eur J Cancer 27: 62-67

Zeng H, Liu GS, Rea PA, Kruh GD (2000) Transport of amphipathic anions by human multidrug resistance protein 3. Cancer Res 60: 4779-4784 